\title{
Transition to democracy in Tunisia: Learning about citizenship in a national and transnational context ${ }^{\prime}$
}

Social Science Information $1-17$

(C) The Author(s) 2016

Reprints and permissions: sagepub.co.uk/journalsPermissions.nav DOI: I0.| |77/05390|84|6658|5 |

ssi.sagepub.com

\section{Mohamed Nachi}

Professor of Sociology, Faculté des Sciences Sociales, Université de Liège, Belgique, Belgium

\begin{abstract}
In this article devoted to the democratic transition in Tunisia, we will provide an opportunity to reflect once again on the process and dynamics entailed in learning about citizenship in a context of transition. We want to stress the different experiences and various moments or events that contributed to bringing about this 'citizenship' (mouwâtana).
\end{abstract}

\section{Keywords}

citizenship, democratic representation, democratization, democracy, representative democracy, transition, Tunisia, Tunisian diaspora

\section{Democracy is the solution.}

(El Aswany, 2011)2

Having elected the Assembly of the Representatives of the People on 26 October 2014, Tunisians went on to elect a new President of the Republic on 21 December of the same year, ${ }^{3}$ thus bringing to a close a crucial, founding stage in the transition begun after the uprising of 2010-11. Although we may speak of a 'Tunisian exception', it must be remembered that this transition to democracy was turbulent (Beau \& Lagarde, 2014) and characterized by escalating violence (Nachi, 2014). Now a new and no-less-important stage is beginning in which the key challenge is to test not only the legal principles and system but also the new institutions provided for in the 2014 Constitution, which are meant to establish and consolidate a democratic political regime.

\section{Corresponding author:}

Mohamed Nachi, Université de Liège, Faculté des Sciences Sociales, Quartier Agora Place des Orateurs, 3 (B3I) 4000 Liège (Sart-Tilman), Liège, Belgique 4000, Belgium.

Email : M.Nachi@ulg.ac.be 
The transition process has allowed the institutionalization of conflict by compromising a mode of regulation and a political practice that help curtail tensions and overcome divergences. This is what I attempted to demonstrate in my reflection on the three forms of legitimacy. Furthermore this process has laid the legal framework for establishing new legitimate powers, both legislative and executive, as well as defining the new rules of the political game: universal suffrage based on sovereignty of the people; choice of the vote to organize legislative and presidential elections; nature of the political regime (semiparliamentary), and so on. All these decisions were debated, sometimes hotly, in the National Constituent Assembly (NCA), and resulted in consultations and compromises between political parties, but also between the nation's driving forces (unions/employers) and influential groups of civil society, such as the Tunisian Human Rights League or the Association of Lawyers.

Four years after the uprising, we can now assess the scope of this major political change and what has been achieved in the process. Until December 2014, when the presidential elections were organized, Tunisia's future remained uncertain, and all the more because the assassination, in 2013, of two emblematic figures of the Tunisian Left, Chokri Belaïd and Mohamed Brahmi, together with numerous members of the police and military, victims of terrorism, destabilized the country and created an atmosphere of insecurity, fear and violence.

To understand what happened over these four years, it is therefore necessary to put into perspective the social and political logics of change and the difficulties involved in building a new social pact, a new legal order. During this period, protest movements, the mobilization of civil society, public debates, and so on turned out to be key factors in structuring a new democratic order capable of fulfilling the goals of the revolution (equality, liberty, respect for dignity, etc.).

To be sure, the revolutionary process was sparked in December 2010, when Mohamed Bouazizi set himself on fire, and it must now be examined in order to understand its origins and the causes behind it (Allal \& Pierret, 2013). But the uprising did not begin on 14 January 2011 (departure of Ben Ali) nor on 17 December 2011 (Mohamed Bouazizi's self-immolation). It had its beginnings in 'repertories of collective action' (Tilly, 1984) and in earlier social movements, among which the protest movements of 2008-09 in the Gafsa mining area were the most significant, as R. Ben Amor shows in his contribution.

But the most striking feature of this transition period is indisputably the process of learning about citizenship in which Tunisians participated with a great deal of enthusiasm and applied intelligence. It is for this reason that we chose to place this learning process at the heart of our reflection, where it serves as the thread linking all of the contributions in this section devoted to Tunisia.

\section{'Testing' learning about citizenship}

Tunisia is in the process of passing from a situation of transition, marked by uncertainty and indetermination, to the consolidation of a democratic regime (Guilhot \& Schmitter, 2000), which remains to be completed. The task of observing how this 'democratic consolidation' (Schedler, 2001) will be concretized at the institutional level, but also when it comes to political practices, falls to sociologists and political scientists. For the moment, 
what is important to retain from this passage from transition to consolidation is that Tunisia is in the process of constructing a new 'citizenship' (mouwâtana) based on liberty, equality and Tunisians' real participation in the political life of their society, whether through free and transparent elections or through different forms of citizen commitment. These are the new political markers that will be the basis for establishing rule of law and a democratic political regime.

In this symposium devoted to the democratic transition in Tunisia, we will provide an opportunity to reflect once again on the process and dynamics entailed in learning about citizenship in a context of transition. We wanted to stress the different experiences and various moments or events that contributed to bringing about this 'citizenship' (mouwâtana). We regard them as tests involved in learning about citizenship. We also wanted to understand them in a context that was both national and transnational, in order to include the role of the Tunisian diaspora. It was a matter of taking a comparative perspective, as it were, on citizenship in its national and transnational dimensions, its internal and external contexts. In other words we wanted to consider the way Tunisians in the country appropriated the site of politics (Abélès, 1983) in its local configuration, on the one hand, and, on the other, how Tunisians abroad, through their commitments as citizens, contributed to the transfer of political experiences and practices, and thus fashioned and marked with their borrowings the tests involved in learning about citizenship. When it comes to the Tunisian diaspora, it becomes clear democratic representation is a key issue in establishing a direct link with the country. In this regard, J-M Lafleur's contribution is most enlightening, in that she shows the questions involved in the representation and participation of emigrants in the political process through the analysis of several cases. These analyses indicate that we are seeing the emergence of a 'remote political citizenship'.

It should be made clear that citizenship is not a simple legal or social state or status that gives individuals certain political and social rights. Citizenship is basically a 'social and political construct' (Neveu, 2004: 2), whose implications go far beyond the political obligations determined by a legal framework. Citizenship should not be confused with belonging to a given community or social group; the term defines an identity sui generis that is independent of the various forms of (social, religious, cultural) belonging that individuals usually claim. Thus, as C. Neveu stresses, citizenship is not 'an identity among others, but precisely that which sets the individual free from his more or less prescribed forms of belonging' (Neveu 2004: 6). Consequently, there exists a political community that is distinct from the 'community' as Gemeinschaft, based on the 'organic will' of the individuals involved, as F. Tönnies has so ably shown. It is a community of citizens within which the individuals affirm themselves as political subjects and see themselves as being endowed with a 'capacity to take part' (Rancière, 2000: 57). As J. Rancière stipulates, 'the political community is not defined by the coming together of all those who belong to the same community. It is defined by the set of those disputes over belonging. It is the community based on the sharing of these disputes' (Rancière, 2000: $65)$. It is therefore the forms of dispute, disagreement and lack of consensus that contribute to constructing citizenship relations based on what Rancière, following Foucault, calls modes of political subjectivation.

In a context of globalization, the redefinition of citizenship implies that its exercise is no longer homogenous and that it is even less tied to a formally identified territory, 
formerly the nation-state. Two scales are now at work in establishing ties of citizenship and, additionally, in the process of political subjectivation, such that citizenship is deployed on several levels: internal/external, national/transnational, local/global (Sassen, 2007). Citizenship thus becomes plural, and its disjunction from the national space means that it has become deterritorialized. Hence the importance of devoting part of this section to the role of Tunisians living abroad in exercising and learning about citizenship in its transnational dimension.

\section{Democratization in a context of transition}

What do we mean when we speak of 'transition to democracy'? Briefly put, it is a process of the democratization of institutions, of society. This suggests, a contrario, that the said institutions and society are not yet democratized; in other words, democracy is not yet established and the society is in the grip of dictatorship or authoritarian rule. In this case, to democratize implies a fundamental political and cultural change enabling the development of a democratic political culture based on certain principles held to be universal: pluralism, a multiparty system, free elections, guarantee of a number of freedoms (of expression, conscience, etc.), transparent management of public affairs, and so on.

Democratization therefore implies a pro-active approach aimed at bringing about in the social and political order mutations of legal values, of cultural and social policies stemming from the will of the people. One of the founding principles of democratic legitimacy is surely that of the equal dignity of all citizens (Kis, 1989). But democratization cannot be reduced to a simple affirmation of principles or procedures; these must become effective, rooted in reality, embodied in political practices, all of which requires their institutionalization and subjectivation. In this respect, democratization is by definition a work in progress. Not only political commitment but the principles of liberty and respect for dignity have to be continually learned by the collectivity, continually taught, in order for them to become effective and shared by all. It is this internalization that is the result of the learning, education and political socialization that we call subjectivation. As Alain Touraine points out:

It is impossible to choose between a defense of democratic institutions and the popular demand for participation: the only solution is to combine them. Democratization is the subjectivation of political life. (Touraine, 1992)

So, what about the Tunisian situation? Where does the transition to democracy stand? We can distinguish two periods: before and after the first free elections of 23 October 2011. Over the first two months of the year (15 January-15 March 2011), the former government attempted to capture the revolution for its own ends, but in vain.

The first period, the seven months between 15 March and 23 October, can be identified as a process of transition to democracy insofar as it allowed the recognition of a certain number of principles, standards and practices that can easily be associated with the will to establish the initial bases for the installation of a democratization process.

The second period, following the 2011 elections, is consistent with the same logic of transition to democracy, with the distinction that the parties in power (the troika) 
- particularly the party of the majority, Ennahdha - wanted, in the name of electoral legitimacy, to establish their hegemony and control the state apparatus so as to place it at the service of Islamist ideology or private interests. In my own article, entitled 'The three legitimacies of democratic transition' I develop a further reflection on the issues and specificities entailed in each of these periods.

After the 2014 elections and the advent of the Second Republic, Tunisia put the finishing touches on the process of transition to democracy and began a period of consolidation. The institutions elaborated and built during the transition period (Constitution, Assembly, advisory councils, etc.) now needed to be established for the long term and confronted with the reality of exercising (democratically?) political power.

The word 'democracy' often appears here, but can we unpack it, if only briefly? That is what I will now attempt to do.

\section{Democracy and others}

How can we define 'democracy' so that we definitively break with authoritarianism? With no claim to being exhaustive, I would like to outline a few perspectives for analysis, in the hope of being able to come back to this crucial and complex question.

The term 'democracy', as we know, comes from two Greek words: demos (people) and kratia (authority). Democracy consists in placing in the hands of the people (demos) the authority (kratia) to manage the affairs of the city.

To answer the question of definition, then, we need to start from two different senses of the word: a restrictive, narrow meaning, which sees democracy in terms of elections and voting; and a second, broader, extensive meaning, which goes beyond the electoral process and gives primary importance to the 'exercise of public reason' (Rawls, 1997), in other words to public discussion and deliberation; to debate and criticism. ${ }^{4}$ In support of the argument for this second perspective, I will call upon the analyses Amartya Sen, winner of the 1998 Nobel Prize in Economics, developed in two articles translated and brought together by a French publisher in a little book entitled La démocratie des autres. In it he shows in particular how the demands of democracy transcend the ballot box (Sen, 2005: 12).

In answer to the initial question, we can already state that the extensive conception holds out more guarantees for a definitive break with authoritarianism. Why? First of all, the narrow vision of democracy, stricto sensu, often reduces democratization to formal rules and procedures for holding free elections. In a way, elections become an end in themselves and the very essence of democracy. However, historical experience - what is happening in Iraq, for instance - shows that this is a reductionist view, an incomplete version. Seen from this standpoint, democracy would seem to be highly vulnerable and likely to succumb to authoritarianism insofar as it is not (or not sufficiently) rooted in a sociopolitical context and is lacking an institution and cultural grounding. As Sen stresses:

Indeed, voting is only one way - though certainly a very important way - of making public discussions effective, when the opportunity to vote is combined with the opportunity to speak, and to listen, without fear. The force and the reach of elections depend critically on the opportunity for open public discussion. (Sen, 2003: 29) 
Recourse to a broader sense of democracy turns out to be necessary if we are going to conceive of the conditions of its durability and, as a consequence, better its chances of becoming irreversible. The basis of democracy lato sensu goes further than the simple act of voting. The exercise of democracy must leave a large place, within its institutions, for criticism, controversy, free discussion and open debate. Of course, citizens fulfill their electoral duty, express their free choice by voting, but in this perspective they also take part in debates and in so doing participate in the democratic process of decision making. Seen in this light, democracy appears as a demanding political regime - and not a majority-making machine - in which criticism and controversy serve to test citizens' fundamental convictions. These can be deemed to be fair or unfair, acceptable or unacceptable. That is where the essential question of political fairness in a democratic regime comes in. As Sen observes: 'A country does not have to be deemed fit for democracy; rather, it has to become fit through democracy' (Sen, 1999: 4).

Democracy is a continual learning process. But democracy is also a contextualized practical experiment that can draw inspiration from the tradition, history or past experiences of a given country. According to Sen:

Democracy has complex demands, which certainly include voting and respect for election results, but it also requires the protection of liberties and freedoms, respect for legal entitlements, and the guaranteeing of free discussion and uncensored distribution of news and fair comment.

(Sen, 1999: 9-10)

Considered from this angle, democracy has several merits and supposes a plurality of values if it is to work. A. Sen retains three principle ways in which democracy enriches the life of citizens.

1. Participation in political and social life has an intrinsic value for people's lives and well-being. It is a major deprivation to be prevented from taking part in the political life of one's community.

2. Democracy has an instrumental value in that it amplifies the hearing given to people when they express and defend their claims to the attention of the political class.

3. Democracy has a constructive function in that it gives people an opportunity to learn from each other and to develop their values, rights and obligations, all of which helps society to shape its values and provide a basis for its choices and projects.

Lastly, democracy can be regarded as a set of tests that are invented and carried out in the site of political life. It is in this site that popular power, people power, whose vocation is to array itself in opposition to institutional power, to the legitimate power holders, primarily imposes itself. People power has its own political practices. In a different perspective, that of direct democracy for instance, people power needs to preserve its right to monitor the established power holders; a right to criticize, even to revoke, the mandates of elected officials (imperative); all so that the population conserves its autonomy and permanent authority. 
But the site of politics affirms itself within the population as well, through new forms of political resistance and action, what Partha Chatterjee calls 'political society' as opposed to the civil society reserved for a specific category of the population. Taking the example of India, Chatterjee shows how the indigent, subaltern population works out its own forms of political action in response to the government's political action (Chatterjee, 2009). This 'politics of the governed' cannot be captured by the classic political categories: representation, delegation, civil society, etc. Hence the need to acknowledge the right of the governed to determine their own forms of political action and to define their own political expectations and demands.

These questions about democracy and the effort to problematize it can, it seems to me, serve as a starting point to think about the questions of democratization and democracy in Tunisia. I concede that this may well be far from the immediate preoccupations of the Tunisian people. Nevertheless, it seems opportune to seize the moment of transition in order to look beyond the simple representative forms of democracy, which are going through a deep crisis, and to work on inventing a 'different democracy', whose matrix remains to be determined by the Tunisian people themselves.

Still, it must be added that it is at the level of 'local democracy' that Tunisia has been most innovative. As Souhail Belhadj's contribution shows, the most significant advances in institutional change have occurred at the local government level rather than at the level of the central state. In effect, the 2014 Constitution establishes a true 'local power' with broad prerogatives, and this permits the passage from a 'hypercentralized State to a decentralized State'. 5 Is it necessary, in order to invent a 'different democracy', to go through representative democracy? Is this an obligatory step?

\section{Representative democracy}

It cannot be overstressed: usually when 'democracy' is talked about, what is meant is liberal representative democracy. But this is only one variant among other forms of the democratic exercise of power. We must therefore distinguish among several forms of democracy: deliberative, participative, direct, radical and so on.

Specialists are unanimous in saying that, today, representative democracy is in crisis, it is suffering from a lack of democracy: crisis of legitimacy, of representation, of participation, etc. But this crisis is visceral (in the original sense of the word), linked to the very nature of democracy and inherent in its mode of being. Jean-Jacques Rousseau (2001) had already established an implacable diagnosis: 'As soon as the people allows itself to be represented, it loses its freedom'. Consequently, representation (or delegation) is not the solution but the problem. What can be done? What is the solution? Is it enough to inject a dose of participative democracy to remedy the democratic shortcomings from which Western political regimes suffer? Certainly not! One of the founders of American democracy, Thomas Jefferson, had already thought of a remedy: 'All the ills of democracy can be cured by more democracy' (quoted in Barber, 1997: 13). 'More democracy', to be sure, but how? The most imaginative liberal authors argue for a little more participation and direct democracy, that is in fact, more frequent recourse to referendums, consultations, etc. Jürgen Habermas, in turn, calls for a deliberative democracy. 
Representative democracy is based on delegation: the citizens delegate their powers to elected representatives. But we know how this works in reality! The interests of the elected representatives rarely coincide with those of their electors. Power becomes concentrated in the hands of an oligarchy, a privileged elite (the rich, experts, professional politicians, etc.) who, no longer serving the people, confiscate their power and monopolize sovereignty. The gulf between those who govern and those who are governed grows! And yet, in the beginning, "the fundamental principle of democracy [was] not representation, elections, but the lottery, the only way of avoiding the confiscation of power by a specialized class' (Rancière, 2011: 315).

For some, with the evolution of Western societies, this representative form of democracy is supposed to turn into deliberative democracy, promoting public discussion, rational debate as theorized by Habermas in the form of debate among diverging interests (Habermas, 1997). In this instance, we can oppose J. Rancière's argument to that of Habermas, who considers that political struggle cannot be reduced to rational debate among diverging interests but involves struggles to make oneself heard and to gain legitimacy for one's claims and political actions. It is in the nature of democracy to allow those without a voice, without work, without property, 'the excluded', what Rancière calls 'the share of those without a share', to be heard and recognized, and to have the right to publically defend their rights.

Representative or deliberative democracy does not meet all these requirements, condemned as it is by its own logic of delegation, dependent on its own procedures. This being the case, we must go beyond this logic, beyond the procedural character of the organization of elections, of delegation or deliberation. Here, too, Rancière's argument provides food for thought:

Democracy is neither a form of government nor a form of society; it is the institution of political action itself, in other words, the affirmation of the radical capacity of one and all. It can never be unified in the form of an institutional system. It must unfold continuously through the invention of political systems and subjects. It is affirmation that puts political action there where political action is denied. (Rancière, 2011: 316)

That being said, and in spite of these surely legitimate criticisms, the question of representation remains at the heart of any reflection on democracy. Let us briefly look at what this means.

\section{Democratic representation}

What is a 'representation'? How is the concept of representation defined?

First it must be said that this is a polysemic term that can have several lexicological levels of signification. It can refer to the idea of figuration or reproduction as much as to that of image or mandate. There are several forms of representation: social, individual, collective, symbolic, substantial, procedural, etc.

To represent is to 'stand in the place of', 'to act for or on behalf of', which means to substitute for someone in the exercise of their rights, to defend their interests or to act in their stead. It means to make present something that is absent. To represent means to act 
in the interests of those represented (Pitkin, 2013: 35). In the realm of politics, representation must be central to the expression of social diversity, cultural pluralism, minority claims, etc. As Marcel Gauchet emphasizes:

To represent means to transcend the difference between beings and between groups in order to manifest the truth of the collective in the unity of the collective will, in other words to display the differences present, to ensure their visibility in the public space, to ensure that they remain legible at all points in the political process, that they are not lost in the process of elaborating the collective decision. (Gauchet, 1998: 119-120)

We, too, must briefly explore the concept of 'representation'. In a substantial sense, representation has achieved one of its best expressions in political action inasmuch as it is the manifestation of an act of political will leading to the transfer of power from someone who elects to someone who is elected. It is therefore a form of delegation of power that requires representatives to act in the interests of their electorate.

In a democratic regime, representation is a mechanism that enables representatives to exercise power on behalf and in place of the citizenry. It is a form of political mediation between civil society and the state, the latter being at the service of the former. Furthermore, representation implies the transfer of a 'power' of decision from the represented to a representative. This transfer supposes (mutual) consent and, in a democratic regime, a previously agreed upon procedure (elections) of legitimization that determines the conditions in which this representation is to be exercised. It must be added, however, following Marcel Gauchet, that 'this is not a simple transfer of identical powers, but a transmutation', that is to say a transformation of the very nature of the process of decision-making. One must 'enter into the higher domain of collective decision-making, which has its own logic owing to the aim pursued there, the sovereign power of the political body over itself' (Gauchet, 1998: 121). Gauchet then comes to the conclusion that 'representation is the transfiguring elevation of society within the state'. In truth, he adds, 'the representatives represent the political sphere to the citizenry as much as they represent the citizens within the political sphere' (Gauchet, 1998: 112).

To represent is also, is above all, to enable the collectivity to see itself and to conceive of itself, to apprehend itself by way of image and thought, by providing it with a stage on which these many and shifting realities take on objective reality in the eyes of its members by reflecting back representations of this collectivity, by enabling the actors to decipher its composition and movement. (Gauchet, 1998: 114)

Representation results from election, whereby it acquires its legitimacy and its autonomy, and endows the elected representatives with the (legal) capacity to act in place of, on behalf of and in the interest of the electors. This is in the nature of representative democracy inasmuch as it is based on delegation: the citizens delegate their powers to those who are elected and who are in turn supposed to represent them.

The question of democratic representation is the issue that is raised by the Tunisian diaspora. But before going into this question, we need to specify what we mean by 'diaspora' and to see if this term fits the situation of Tunisians living abroad. 


\section{Diaspora and democratic representation}

The notion of 'diaspora' has become central to reflection on the situation of foreigners and more generally on the migratory phenomenon in all its diversity. An entire field of research, known as 'Diaspora Studies', has grown up in the last decades to tackle questions linked to expatriation and exile; to immigrants and refugees, to foreigners, to minorities; to cultural identities and to their rights. Its increasingly extensive use has become accepted, not without difficulty, after numerous controversies aimed at defining its contours and showing the pertinence of its various uses. I will not go back over the various aspects of the notion and the discussions it has sparked, but will simply say that there are two major approaches: the first starts from an ideal-typical view of the diaspora and goes on to lay out previously determined criteria and features; the second views the diaspora experience in connection with the multiple identities and modern forms of globalization. It is this second approach, developed in the wake of Cultural Studies (Hall, 2008), that I propose to take in an attempt to nourish the reflection on and define the theoretical potential of the concept of diaspora.

As Stéphane Dufoix has already pointed out, ${ }^{6}$ the term 'diaspora' is not neutral: the choice to use it has become an issue insofar as it creates that of which it speaks. The fact of talking about 'diaspora' is a performative act that is not limited to describing a reality but which expresses a normative position in doing so. After having long carried a pejorative connotation, its use began to spread in the late 1990s as it joined the lexicon of international organizations but also of the social sciences. Since then an entire field of research has grown up under the label of 'Diaspora Studies'.

Generally speaking, the term diaspora means dispersal, spatial dissemination, migratory mobility, but also roots, a unity and more or less affirmed ties between different groups of a scattered community. Diaspora thus necessarily entails a transnational dimension. Among the countless definitions, we can retain the following:

As it is used in politics and sociology, the term diaspora designates the geographical dispersal of ethnic groups which, forced to live away from the group to which they belong, have been integrated, in one manner or another, as a minority in a different society and are faced, owing to their twofold belonging, with grave problems in their search for an identity and in the clarification of their interests. (Hettlage, 2012: 174)

It appears that the study of a diaspora must be organized around a triptych: a diasporic population, a place of residence and a place of origin. The double belonging is central, in particular to the elucidation of the question of representation, insofar as the diaspora population finds itself expatriated from the habitual space that defines its loyalty and nationality. As Stéphane Dufoix has pointed out, ${ }^{7}$ we are no longer faced with what Abdelmalek Sayad (1999) called a 'double absence', in which immigrants are forgotten both in their home country and in their host country, but with a 'double presence', insofar as immigrants can now be 'present' in several different places. It is this ubiquity that has given rise to the bond between states and their nationals. This double belonging supposes the extra-territorialization of the nation, which includes not only nationals (citizens), but also extra-nationals (foreigners). Citizenship is no longer determined solely by a legal bond (state) or a territorial tie (nation), but also by diasporic (political) linkages. The 
latter are expressed through voting rights, parliamentary representation of the diaspora, the creation of representative bodies (advisory councils), the creation of extraterritorial circumscriptions, etc. The key challenge for the diaspora is to maintain a real link with the home country, even if, in certain cases, this can give rise to torn loyalties. Because of this, the diaspora has a transnational dimension that is expressed though, among others, democratic representation, and this leads to redefining the notion of citizenship. As Seyla Benhabib points out:

Today we are seeing not only a reconfiguration of the notion of sovereignty, but also reconstitutions of citizenship. We are moving further and further away from citizenship understood as a sign of national belonging and toward a citizenship of residence that strengthens the multiple ties with local and regional levels, and with transnational institutions. (Benhabib, 2007: 197)

For the nation-state, the diaspora is a source of political and economic support, but at the same time it implies a plurality of forms of allegiance and political commitment.

Nevertheless, in practice, states remain reticent about representation of their nationals living abroad. In this respect, diasporas in general, and the Tunisian diaspora in particular, have often found themselves denied recognition, deprived of their political rights and regarded as second-class citizens. They therefore usually lack representation in the host country (voting rights for foreign nationals) and are refused representation in their home country. Immigrants are outcastes, as it were, in the modern political world, excluded from the democratic process.

In the host country, as we know, the right to vote is still a fraught question. Already in the nineteenth century, even though he was one of the major theoreticians of liberal democracy, Tocqueville considered mass immigration to be a danger that threatened America with the 'greatest peril'. 'What frightens me', he wrote, 'is the huge number of foreigners that makes of us a new people' (Tocqueville, quoted in Losurdo, 2007: 17). He was hostile to the idea of granting political rights to immigrants.

For their part, the original nation-states have until recently refused their diasporas any form of representation. It has been only since the late 1990s that states have begun to show an interest in their nationals by relaxing the laws concerning double nationality or accepting their participation in national political life through, in particular, two forms of representation: the right to vote and the creation of representative bodies, such as advisory councils.

I will take the example of Tunisia.

\section{What brand of democratic representation for the Tunisian diaspora after the uprising?}

As we said above, the key issue involved in representation is the inclusion of the different components of society so as to preserve differences and ensure the 'public enactment of social diversity'. The Tunisian diaspora is a component of Tunisian society and as such demands the right to be represented. ${ }^{8}$

Indeed, one of the main demands of Tunisians living abroad is for a body to represent them, to defend their interests and to transmit their demands to the competent Tunisian 
authorities. This demand is not new, but the process of transition to democracy and the new dynamic that has emerged in civil society have consolidated it and have been active in the creation of an unprecedented public debate.

It is true that great hope was born in the Tunisian diaspora following the 2011 uprising. But this uprising also had contradictory effects: on the one hand, it allowed a dynamic to emerge that re-activated feelings of belonging and recourse to a 'diasporic national reference'; but on the other hand, it exacerbated the tensions and divergences within this dispersed community. That being said, since the uprising, we have seen the emergence of a new awareness visible in the organization of cultural activities, activist groups, forms of civic commitment, the creation of associations, and so on. In most cases the Tunisian diaspora calls on a double normative repertory: one refers to the place of residence and the other to the place of origin. In fact, the two often intertwine, one being used to criticize the other. For example, some Tunisians criticize the corruption or clientelism practiced in Tunisia using the standards and values of the host country.

First of all it must be recalled that the principal agency supposed to deal with immigration is the Office of Tunisians Abroad (OTA), but it has not always lived up to expectations. That is why Tunisians living outside their country have ceaselessly fought for recognition of their rights as Tunisian citizens: the right to participate in the political life of the country (suffrage and eligibility), the right to be considered on a par with other Tunisian citizens and not as second-class citizens, and so on.

After the uprising a new dynamic emerged, and associations and members of civil society mobilized to express their demands and bring the country to establish an immigration policy that took into account the real problems of Tunisians living abroad (Slimane \& Khlif, 2009). A high point of this mobilization was the call to organize a general meeting on Tunisian immigration. The idea of such a meeting arose in February 2011.

An initial encounter was held in Paris on 8 May 2011 at the University of Paris 8 Saint-Denis, which was attended by nearly 350 persons, some 60 associations, and Tunisian committees and collectives from Belgium, Italy, Canada, Sweden, Switzerland, Tunisia and France.

Four commissions were set up: 'Representation', 'Undocumented migrants, harragas and bilateral agreements', 'Young people, culture and mother tongue', 'Reception in consulates during a stay, projects ...'. All of these are important issues for Tunisians as well as for the Tunisian diaspora.

Another, larger meeting was held in Tunis on 25, 26 and 27 June 2011. Among the accomplishments of this transition period, we should recall in particular:

1. From the beginning of the uprising, Tunisians living abroad were invited to sit on the famous High Council for the Realization of the Goals of the Revolution, Political Reforms and Democratic Transition.

2. The creation of a Secretariat in charge of Immigration and Tunisians living abroad, attached to the Ministry of Social Affairs.

3. In the Constituent elections of 22 October 2011 and the 2014 legislative elections, Tunisians living abroad were able to elect representatives to the $\mathrm{NCA}^{9}$ and the Assembly of the Representatives of the People. ${ }^{10}$ 
4. The new 2014 Constitution stipulates in Article 55: 'The electoral law guaranties the right to vote and representation of Tunisians living abroad in the Assembly of the Representatives of the People.'

These are very important advances, but they are still not enough. First of all it is clear that, in the NCA, and also in government policy, the Tunisian diaspora does not rank high on the agenda. It is striking that the Constitution contains no provision (with the exception of Article 55) concerning directly or indirectly the Tunisian diaspora. Furthermore, the Minister of Social Affairs (the supervisory minister of the State Secretary in charge of Emigration), Khalil Ezzaouia, clearly stated that 'the government of Tunisia has no official policy on emigration'. To which he added that the representatives could very well act as representatives of Tunisians living abroad. ${ }^{11}$

\section{The importance of a representative body}

Most democratic countries have a body that represents their nationals living abroad.

Conscious of the importance of having a body to represent and speak for them, Tunisians living abroad are anxious to ensure that their demands will be taken into consideration and that they will play a role in Tunisia's transition to democracy and the building of a future state under the rule of law.

Post-revolutionary Tunisia must therefore take a lesson from other countries and set in place a representative body responsible for affairs specific to the Tunisian diaspora. The creation of such a body raises several questions:

1. What is the nature or the structure of this organ to be: advisory or representative?

2. Who should be in charge of setting it up?

3. How should the members of this body be chosen: election, appointment, cooptation, some combination of the foregoing, and so on?

4. How can the associations and members of civil society be brought into the elaboration of this body?

5. How are the political independence and the neutrality of this body to be ensured?

6. How is the proper functioning of this body to be monitored?

Some associations have suggested that this body should be written into the Constitution, but the Constituent Assembly did not retain this proposal. As a consequence, it will be necessary to adopt legal guarantees in order to preserve the democratic and pluralistic character of such a body.

It seems indispensable that the answers to these questions should come from the active participation of the associations involving Tunisians living abroad and the members of civil society (intellectuals, workers, scientists, etc.) This could be made to happen by setting up working commissions in each country that would be asked for concrete suggestions.

The first step is to get a clear picture of the status quo:

1. See how other countries have envisaged the question of representing their nationals living abroad, so as to learn from their experiences. 
2. Draw up a list of suggestions based on discussions and participation of those concerned (associations, civil society, etc.).

The subject remains open, but Tunisian civil society seems determined to pursue this process and to gain official representation.

\section{The organization of this symposium}

The present symposium, which I have coordinated, is the outcome of collaboration among several researchers who have agreed to contribute their different views, each from the standpoint of their research area, on the many facets of the situation in Tunisia after the 2010-11 uprising. The symposium is therefore devoted to the transition to democracy as experienced in Tunisia (2011-14). The articles are articulated around a common denominator, which is a topic that cuts across all their domains, that of the process of learning about citizenship in a post-revolutionary context.

The reflection revolves around two dimensions of citizenship mentioned in the previous pages, namely the national and the transnational. In the case of the latter, one contribution is devoted to the issues of representation of the diaspora and political participation by Tunisians living abroad. J.-M. Lafleur's text sets out the theoretical framework for a general reflection on the participation of emigrants in elections in their home country; his reflection is based on several examples of states that have put in place specific mechanisms for representation and consultation so that their nationals residing abroad may exercise their citizenship by participating in the political life of the country or, more specifically, by voting by absent voter ballot. These analyses lead him to investigate the emergence of what he calls 'external political citizenship', of which he lists three main dimensions: consultative, representative and participative. The exercise of citizenship is thus multiple.

In sum, this contribution shows how the diaspora is the source of a new form of citizenship - which can be called 'remote' - of which the challenge is to reconfigure the site of the political, and in so doing, to fashion the way one learns about citizenship.

The following three contributions look at the multiple national dimensions of citizenship from different but complementary points of view. R. Ben Amor analyses the 'revolutionary process' and seeks to shed light on the passage from protest to the exercise of citizenship. Basing his reflection on empirical studies, he develops the idea of a continuity between the 2010-11 uprising and the social protest movements that preceded and in a certain manner prepared it, in particular the 2008 movement in the mining basin. Regarded as a revolt before the 'revolution', this movement was not necessarily a precursor to the revolutionary commitments of 2010-11, but it prepared minds and became a leitmotiv for people's engagement in the revolution. After the uprising, the transition period was characterized by a proliferation of protest sites, which enabled the passage from passive citizenship to active citizenship.

Souhail Belhadj's text studies the institutional recomposition of local collectivities during the 2011-14 transition period. He shows how we are seeing a profound change in political life that is going to give these collectivities unprecedented power. He deems that this led to passing from the hypercentralization of the old regime to the emergence, 
during the transition period, of a real 'local government that is largely independent (in terms of finances and administration) of the central government. The promulgation of the new Constitution, arrived at through a historical compromise between the representatives of the country's different political persuasions, laid new legal foundations for local government, thus preparing the advent of 'local participative democracy'. New rules for a multiparty political system can be established on this basis and thus consolidate the process of learning about citizenship at the local level.

In the final contribution, I analyze the way Islam became a 'public problem' in Tunisia after the 2010-11 uprising. Taking as my starting point several 'affairs' and controversies surrounding Islam, I examine the place of religion in the public space both before and after the 2011 elections. This development of 'public Islam' is part of the reconfiguration of Tunisian civil society and its extension after the 2011 uprising. During this transition period, civil society became a site of political expression, protest and citizen commitment, thus becoming the prime place for learning about citizenship. Citizenship clearly appears to have played a role in the transition to democracy, not only because of the milestone political events but also because of the public debates and the protest movements that marked this period.

\section{Notes}

1. Some of the text in this article was originally presented at the study day I organized at the University of Liège on 28 September on the topic 'The Tunisian diaspora: What kind of democratic representation?'

2. It is with this phrase that the famous Egyptian write, Alaa El Aswany, author of, among others, the novel The Yacoubian Building, ends each of the chapters of his On the State of Egypt: What caused the revolution. This phrase echoes what for years was the leitmotif of the Muslim Brotherhood and the Islamist movements in general, which consider that 'Islam is the solution'.

3. On Monday 22 December 2014, the Instance supérieure indépendante pour les élections (ISIE) officially announced the results of the second round of voting in the presidential elections: Mohamed Beji Caïd Essebsi had been elected president of Tunisia's second Republic, with $55.68 \%$ percent of the votes as against $44.32 \%$ for Moncef Marzouki.

4. This distinction corresponds to a certain extent with that which Benjamin Barber makes between 'weak' and 'strong' democracy (Barber, 1997).

5. Chapter 8 of the 2014 Constitution devotes 11 articles to 'local power'.

6. Paper given at the 'Tunisian diaspora' study day, 28 September 2013: 'Chacun sa diaspora ... Les transformations des politiques étatiques envers les expatriés'.

7. Paper given at the 'Tunisian diaspora' study day, 28 September 2013: 'Chacun sa diaspora ... Les transformations des politiques étatiques envers les expatriés'.

8. A reminder of a few basic statistics. Tunisians living abroad are an integral part of the national community; they represent over $10 \%$ of the Tunisian population, or 1,200,000 persons living in different countries of Europe, Asia, North America and Africa. They are the equivalent of two Tunisian governorates and are the second source of monetary contributions to the national economy. They are distributed as follows: nearly 600,000 in France (54\%), over 150,000 in Italy (14\%), over 85,000 in Germany and Libya (8\%). These five countries account for $84 \%$ of the Tunisian community abroad. But Tunisians are present in other countries and regions as well: 23,000 in Benelux, 13,000 in Switzerland, 18,000 in Saudi Arabia, 16,000 in Algeria, 13,000 in the Emirates, 15,000 in Canada and 13,000 in the United States. 
9. In the National Constituent Assembly elections in October 2011 and the 2014 legislative elections, there were 217 seats to be filled. Of these, the diaspora was allocated 18 seats, divided among 6 electoral circumscriptions:

\begin{tabular}{lll}
\hline Circumscription & Place & Number of seats to be filled \\
\hline France I & $\begin{array}{l}\text { Consulates of Paris, Pantin and } \\
\text { Strasbourg }\end{array}$ & 5 \\
France 2 & Consulates of Lyons, Toulouse, & 5 \\
Grenoble, Nice and Marseilles & \\
Italy & Italy & 3 \\
Germany & Germany & 1 \\
Americas and rest of Europe & Americas and rest of Europe & 2 \\
Arab countries and others & Arab countries and others & 2 \\
\hline
\end{tabular}

10. According to the ISIE, participation in the elections reached $62 \%$. Abroad (the diaspora), the percentage was $29 \%$ on average, which is very low.

11. Declaration of 20 January 2013, at the conference on the social pact signed by the government, the UTICA and the UGTT in Paris, in the presence of the Tunisian ambassador to France.

\section{References}

Abélès M (1983) Le lieu du politique. Paris: Société d'Ethnographie.

Allal A, Pierret T (eds) (2013) Au cour des révoltes arabes. Devenir révolutionnaires. Paris: Armand Colin.

Barber BR (1997) Démocratie forte. Paris: Desclée de Brouwer.

Beau N, Lagarde D (2014) L'exception tunisienne. Chronique d'une transition démocratique mouvementée. Paris: Le Seuil.

Benhabib S (2007) Crépuscule de la souveraineté ou émergence de normes cosmopolites? Repenser la citoyenneté en des temps volatiles. In: Wieviorka M (ed.) Les sciences sociales en mutation. Paris: Editions Sciences Humaines, 183-204.

Chatterjee P (2009) Politique des gouvernés. Réflexions sur la politique populaire dans la majeure partie du monde. Paris: Editions Amsterdam.

El Aswany A (2011) Chroniques de la révolution égyptienne. Paris: Actes Sud.

Gauchet M (1998) La religion dans la démocratie. Parcours de la laïcité. Paris: Gallimard.

Guilhot N, Schmitter PC (2000) De la transition à la consolidation. Une lecture rétrospective des democratization studies. Revue française de science politique 50(4-5): 615-631.

Habermas J (1997) Droit et démocratie. Entre faits et normes. Paris: Gallimard.

Hall S (2008) Identités et cultures. Politiques des Cultural Studies. Paris: Editions Amsterdam.

Hettlage R (2012) Diaspora: Esquisse d'une théorie sociologique. Tracés. Revue de sciences humaines 23: 173-195.

Kis J (1989) L'égale dignité. Essai sur les fondements des droits de l'homme. Paris: Le Seuil.

Losurdo D (2007) Démocratie ou bonapartisme. Triomphe et décadence du suffrage universel. Paris: Le Temps des Cerises.

Nachi M (2014) Révolution et transition démocratique en Tunisie. L'invention d'un nouveau compromis politique? In: Munera L, Nanteuil M de (eds) La vulnérabilité du monde. Démocraties et violence à l'heure de la globalisation. Louvain-la-Neuve: Academia-Bruylant, 207-221. 
Neveu C (2004) Les enjeux d'une approche anthropologique de la citoyenneté. Revue Européenne des Migrations Internationales 20(3). Available at : http://remi.revues.org/2024.

Pitkin HF (2013) La représentation politique. Raisons politiques 50(2): 35-51.

Rancière J (2000) Citoyenneté, culture et politique. In: Elbaz M, Helly D (eds) Mondialisation, citoyenneté et multiculturalisme. Paris: L'Harmattan/Presses Universitaires de Laval, 55-68.

Rancière J (2011) Politique et esthétique. Un entretien de Jean-Marc Lachaud avec Jacques Rancière. Actuel Marx. 25 ans d'Actuel Marx, 311-321.

Rawls J (1997) The idea of public reason revisited. The University of Chicago Law Review 64(3): $765-807$.

Rousseau J-J (2001) Du contrat social. Paris: Flammarion-GF.

Sassen S (2007) La globalisation. Une sociologie. Paris: Gallimard.

Sayad A (1999) La double absence. Des illusions de l'émigré aux souffrances de l'immigré. Paris: Le Seuil.

Schedler A (2001) Comment observer la consolidation démocratique? Revue Internationale de Politique Comparée 8(2): 225-244.

Sen A (1999) Democracy as universal value. Journal of Democracy 10(3): 3-17.

Sen A (2003) Democracy and its global roots. The New Republic 6 (October): 28-35.

Sen A (2005) La démocratie: des autres. Pourquoi la liberté n'est pas une invention de l'Occident. Paris: Payot. (This volume results from the translation of Sen (1999) and Sen (2003)).

Slimane L, Khlif W (2009) Les compétences tunisiennes à l'étranger: Peut-on parler d'une diaspora scientifique? L'Année du Maghreb V: 421-436.

Tilly C (1984) Les origines du répertoire d'action collective contemporaine en France et en Grande-Bretagne. Vingtième Siècle. Revue d'histoire 4(1): 89-08.

Touraine A (1992) Critique de la modernité. Paris: Fayard.

\section{Author biography}

Mohamed Nachi was born in Tunisia, and is a legal scholar trained in anthropology and sociology. His research is focused on political and moral sociology and sociology of Islamic cultures and thought. After teaching at the Catholic University of Leuven (Belgium) and at the University of Sfax (Tunisia), he is presently professor of sociology in the department of Social Sciences at the University of Liège (Belgium). His publications include: Ethique de la promesse. L'agir responsable (PUF, 2003), Introduction à la sociologie pragmatique (A. Colin, 2006), Actualité du compromis. La construction politique de la difference (A. Colin, 2011) and Les Figures du compromis dans les sociétés islamiques (Karthala, 2012). 